\title{
Total Lymphocyte Count, Neutrophil-Lymphocyte Ratio, and Platelet-Lymphocyte Ratio as Prognostic Factors in Advanced Non-Small Cell Lung Cancer with Chemoradiotherapy [Corrigenudm]
}

Song X, Chen D, Yuan M, Wang H, Wang Z. Cancer Manag. 2018;10:6677-6683

On page 6677, Abstract, Results subheading, the median baseline PLR should be 136.1 .

On page 6680 , Results section, $2^{\text {nd }}$ paragraph, the median baseline PLR should be 136.1 .

On page 6680 , the red curve should be PLR $\geq 136.1$ and the blue cure should be PLR $<136.1$. The COX analysis was not correct in the previous publication and it has been revised and shown below in the new Tables 1 and table 2 . The correct Figure 3 is shown below.

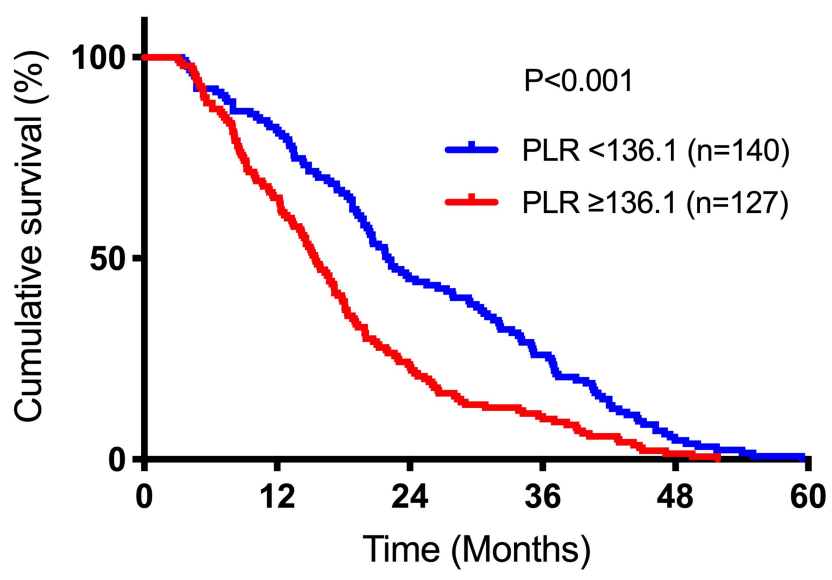

Figure 3 Kaplan-Meier plots of overall survival among patients who receivedchemoradiotherapy for advanced NSCLC stratified by baseline PLR.

Abbreviations: NSCLC, non-small cell lung cancer; PLR, platelet-tolymphocyteratio.
On page 6680, Table 2, the COX analysis was not correct in the previous publication and it has been revised. The correct Table 2 is shown below.

Table 2 Univariate analysis of factors potentially associated with overall survival

\begin{tabular}{|l|l|l|l|}
\hline Characteristics & HR & $\mathbf{9 5 \%} \mathbf{C l}$ & P Value \\
\hline Age $\geq 65$ & 0.778 & $0.609-0.994$ & 0.045 \\
Male & 0.935 & $0.733-1.193$ & 0.588 \\
KPS score $\geq 70$ & 1.100 & $0.762-1.588$ & 0.611 \\
TNM stage IIIB & 1.024 & $0.763-1.375$ & 0.874 \\
Current smoker & 0.918 & $0.748-1.126$ & 0.412 \\
Receipt of induction & 1.127 & $0.88 I-1.443$ & 0.342 \\
chemotherapy & & & \\
Receipt of concurrent & 0.868 & $0.660-1.143$ & 0.314 \\
chemotherapy & & & \\
Pretreatment TLC $\geq 2.4 \times 10^{3} / \mu \mathrm{L}$ & 0.594 & $0.464-0.759$ & $<0.00 \mathrm{I}$ \\
Pretreatment NLR $\geq 3.4$ & 2.280 & $1.776-2.927$ & $<0.00 \mathrm{I}$ \\
Pretreatment PLR $\geq 136.1$ & 1.745 & $1.364-2.232$ & $<0.00 \mathrm{I}$ \\
\hline
\end{tabular}

Abbreviations: $\mathrm{HR}$, hazard ratio; $\mathrm{Cl}$, confidence interval; ECOG PS, Eastern Cooperative Oncology Group performance status; TNM, tumor-nodes-metastasis; TLC, total lymphocyte count; NLR, neutrophil-to-lymphocyte ratio; PLR, platelet-to -lymphocyte ratio.

On page 6681, Table 3, the COX analysis was not correct in the previous publication and it has been revised. The correct Table 3 is shown below. 
Table 3 Multivariate analysis of factors potentially associated with overall survival Model I (TLC included)

\begin{tabular}{|c|c|c|c|c|c|c|c|c|c|}
\hline & \multicolumn{3}{|c|}{ Model I (TLC Included) } & \multicolumn{3}{|c|}{ Model 2 (NLR Included) } & \multicolumn{3}{|c|}{ Model 3 (PLR Included) } \\
\hline & HR & $95 \% \mathrm{Cl}$ & P Value & HR & $95 \% \mathrm{Cl}$ & P Value & HR & $95 \% \mathrm{Cl}$ & P Value \\
\hline Characteristics & & & & & & & & & \\
\hline Age $\geq 65$ & 0.902 & $0.697-1.167$ & 0.431 & 0.858 & $0.67-1.099$ & 0.226 & 0.825 & $0.645-1.054$ & 0.124 \\
\hline Pretreatment TLC $\geq 2.4 \times 10^{3} / \mu \mathrm{L}$ & 0.613 & $0.474-0.794$ & $<0.001$ & & & & & & \\
\hline Pretreatment NLR $\geq 3.4$ & & & & 2.231 & $1.734-2.87$ & $<0.001$ & & & \\
\hline Pretreatment PLR $\geq 136.1$ & & & & & & & 1.71 & $1.333-2.185$ & $<0.001$ \\
\hline
\end{tabular}

Abbreviations: HR, hazard ratio; Cl, confidence interval; ECOG PS, Eastern Cooperative Oncology Group performance status; TNM, tumor-nodes-metastasis; TLC, total lymphocyte count; NLR, neutrophil-to-lymphocyte ratio; PLR, platelet-to-lymphocyte ratio.

The authors have advised errors were caused by carelessness and mis-operation in statistics.
The authors apologize for this error and advise it does not affect the results of the paper.

\section{Publish your work in this journal}

Cancer Management and Research is an international, peer-reviewed open access journal focusing on cancer research and the optimal use of preventative and integrated treatment interventions to achieve improved outcomes, enhanced survival and quality of life for the cancer patient.
The manuscript management system is completely online and includes a very quick and fair peer-review system, which is all easy to use. Visit http://www.dovepress.com/testimonials.php to read real quotes from published authors. 